\title{
Integrated Reporting, Sustainable Development Goals and the Role of Regional Information System
}

\author{
Syaiful Hifni", Akhmad Sayudi, Atma Hayat, A. Kadir, Rano Wijaya \\ Faculty of Economic and Business, Lambung Mangkurat University, Banjarmasin, Indonesia
}

Received February 12, 2021; Revised May 7, 2021; Accepted June 6, 2021

\section{Cite This Paper in the following Citation Styles}

(a): [1] Syaiful Hifni, Akhmad Sayudi, Atma Hayat, A. Kadir, Rano Wijaya, "Integrated Reporting, Sustainable Development Goals and the Role of Regional Information System," Universal Journal of Accounting and Finance, Vol. 9 , No. 3, pp. 362 - 371, 2021. DOI: 10.13189/ujaf.2021.090310.

(b): Syaiful Hifni, Akhmad Sayudi, Atma Hayat, A. Kadir, Rano Wijaya (2021). Integrated Reporting, Sustainable Development Goals and the Role of Regional Information System. Universal Journal of Accounting and Finance, 9(3), 362 - 371. DOI: 10.13189/ujaf.2021.090310.

Copyright $\bigcirc 2021$ by authors, all rights reserved. Authors agree that this article remains permanently open access under the terms of the Creative Commons Attribution License 4.0 International License

\begin{abstract}
Purpose: The purpose of this research article is to assess what information should be connected and how its information can be connected based on integrated thinking fit within integrated reporting $<\mathrm{IR}>$ into information system of regional investment potential (ISRIP) of regional government. To develop insight into how it can be implemented over changes of investment climate due to the top down pressures to fulfill sustainable development goals (SDGs). Design/methodology/approach: we conducted research for regional governments (province/district/city) in Indonesia with investment characteristics of the potential, priorities and opportunities of regional investment units by taking samples for 100 regional investment units. Measurement used nominal scale with chi-square test for goodness of fit to get the measurement of observation frequency (OF) and compared with the expected frequency (EF). Findings: the measurement results showed observed frequency (OF) with a value of 137.97. Afterwards, for expected frequency (EF), with degrees of freedom (6-1) (7-1) and a significance level of 0.05 , within the chi- square showed the value of 43.77. Due to $\mathrm{OF}>\mathrm{EF}$, this result indicated for being of corresponding between integrated thinking of regional investment within implementation of information system of regional investment potensial (ISRIP). The level of integrated thinking relationships with integrated reporting $<\mathrm{IR}>$ in the role of "ISRIP" has a Pearson contingency coefficient of 0.4057 , as a moderate relationship. Originality: This research article contributes to the growing debate about the benefits of integrated
\end{abstract}

reporting as a voluntary reporting initiative, and in which another organization have adopted $<\mathrm{IR}>$ as a mandatory initiative for the mode of reporting up to date; more specifically, in the efforts of regional governments to adopt an integrated thinking that is in line with the role of an integrated reporting system, in communicating of regional investment units. Practical implications: To be as an early adopter of $\langle\mathrm{IR}>$ reporting practices towards the implementation of the information system of regional investment potential (ISRIP). We imply that the six capital $<\mathrm{IR}>$ with strategic communication will enhance performance of ISRIP, through fundamental way and as regional strategic wisdom. To meet the values of accountable organization within regional investment units' management. In line with national alignment in global megatrends with the sustainable development goals (SDGs) accomplishment.

Keywords Integrated Thinking, Integrated Reporting $<\mathrm{IR}>$, Regional Investment, Information System for Regional Investment

\section{Introduction}

Public Investment Management needs to be done with effective investment communication. To manage this public investment at various levels, besides effectiveness, the government also needs to enhance efficiency by 
coordinating, strengthening capacities, and ensuring a healthy framework at all levels of government [1]. Furthermore, this investment communication fulfillment in context of sustainable development will be related to environmental management systems [2]. This relates to development and audit to investment accountability. As implementing of a reference related to the international standard ISO 14001 [3]. Investment management in Indonesia for sustainable development has been stated within the vision of the general plan of investment until year of 2025 for Indonesia. With the aim for "sustainable investment in the framework of realizing an independent, advanced, and prosperous Indonesia [4][5].

Indonesia as part of the global community need the effective investment communication, referring to investment decisions according with the implementation of social and environmental responsibilities (Law No. 25 of 2007). More than about financial achievement for investment [6], that investment has relationship with environmental principles that are sustainable and environmentally sound by promoting sustainable economic development (Law No. 32 of 2009) [7]. Based on these regulations or guidelines, all activities related to investment management are carried out by fulfilling the requirements for sustainable investment for sustainable development. Such as investment requirements to fulfill a strategic environmental assessment that must be carried out before obtaining an investment permit. Therefore, this is the main thing for all investment management regulatory approaches in Indonesia that must be in line with the global context in the management of public investment (Presidential Regulation, No. 16 of 2012) [4][5]. Until now, efforts to meet the sustainability of development through investment activities have been pursued [4][5]. The purpose of this research article is to assess what information should be connected and how its information can be connected based on integrated thinking fit within integrated reporting $<\mathrm{IR}>$ into information system of regional investment potential (ISRIP) of regional government. To develop insight into how it can be implemented over changes of investment climate due to the top down pressures to fulfill sustainable development goals (SDGs). The benefit of the normative model of investment management development is to support the role of ISRIP according to the promotional strategy approach carried out in 3 (three) groups of regional investment potential [4]. Therefore, it is stated whether there are aspects (integrated thinking and aspects of a connecting functional department), meeting an alignment with strategic communication and with the information criteria towards on regional investment units that are potential, priority and investment being ready to be offered. Therefore, this study aims to answer 2 (two) following questions: (i) are there differences in ISRIP performance within regional investment units that worth to be offered, with the fulfillment of aspects (connecting strategy, governance, past performance, future prospects, and connecting functional departments) (ii) are there relationship in ISRIP performance within regional investment units that worth to be offered, with the fulfillment of aspects (connecting strategy, governance, past performance, future prospects, and connecting functional departments). The benefit of this research is to provide insight within the development of regional investment management. Being through by the information system of regional investment potential (ISRIP) as an accountability tool that according to the harmony within achievement of the SDGs.

\section{Literature Review}

The global development communication has mandate referring to sustainable development in accordance with the integration of the SDGs [7] throughout the investment cycle. Furthermore, where public investment management must be able to contribute to sustainable development targets [8]. This is a moral aspect within an investment ethics [9], in line with ethics in the use of information technology [10]. Investment management is implemented with the support of information system functions and roles. Until this time being, the Government of Indonesia establishes regional investment management in the types of potential investments, investment priorities and leading investments or investment opportunities that are ready to be offered. There are two kinds of approach to determine types of superior investments to be offered for investros. First, are determined by capital investment coordination board (CICB), with from top to bottom up approach, namely through by selection for the regional governments within the regional champion program. Otherside, with another approach through by the promotion of regional investment which determined from the bottom up through the proposed the provincial, regency and city governments [4].

Normatively, to fulfill the role of information system performance, it is necessary to orientate towards an integrated reporting system model [11][12][13][14]. This reporting system is a reporting model developed and refining the sustainable reporting system [15] or triple bottom line reporting [16] from Global Reporting Initiatives [17];[18]. As it is known that the above reporting types only result in an evaluation of historical value. Therefore, relevant efforts can be considered with integrated thinking fit with integrated reporting $<\mathrm{IR}>$ towards creating value over time [11], [12], [13], [14], [19], [20], [21]. For fulfillment the performance of the function and role of information system of regional investment potential (ISRIP) [4][5]. Due to the implementation of investment management requires the communication for all of information which needed by investors. For their investments decision, in which of the region which be easily accessible, and with availability for comprehensive 
information within "ISRIP"on the website [5]. In this context, the CICB has established a national information system through by the regional governments, which manages information on potential investment on the www.regionalinvestment.bkpm.go.id website with the name "information system regional investment potential (ISRIP). Functionally and according to its role, an information system really needs its development to fulfill the completeness of contents and basic communication methods. An information system such as for regional investment management is designed to meet the performance of the information system. As an implementation of investment cycle communication [8] that meets investment management accountability requirements for global development sustainability [7].

Functionally, until now, the implementation of "ISRIP" through websites which are managed by regional governments has limited investment information, where most regions have not updated the data. This hampers the effectiveness of information communication which is implemented as a decision reference for investors. Meanwhile, in deciding to invest in an area, investors need investment information that is easily accessible and comprehensive on one site [22][23]. Until now, data updating was carried out by each region, meanwhile otherside, most of the regions had not updated it. For the sake of effectiveness of "ISRIP", [5] capital investment coordination board (CICB), has overhauled this system with the completeness of content and role of information. It includes perspective content element in ISRIP, such as, information for why Indonesia, investment opportunities, incentives, OSS licensing, infrastructure, and potential companies that are ready to partner with up dates on collaboration data/links between Ministries/Institutions and business associations. The capital investment coordinating board (CICB) developed of investment potential information in the ISRIP. Also, CICB encouraging competition between regions in increasing investment potential and updating data on the website. The focus is on 5 (five) provinces that are very promising and investment friendly which will be circulated and communicated every three months to be pushed to become regional investment champions through by the role of "ISRIP". The focus of the first phase of investment is in the Java region, namely West Java, Banten, DKI Jakarta, Central Java and East Java [24][4].

Based on the state of condition of investment management in Indonesia, it can be seen that there are challenges in investment management today. There are challenges in the management of domestic direct Investment (DDI) and foreign direct investment (FDI) in terms of equitable growth. Data on investment realization based on investment sector and location shows the distribution of investment, around $60 \%$ is still concentrated in Java and $40 \%$ outside Java. Among 34 (thirty-four) provinces with 514 (five hundred and fourteen) districts/cities, shows investment activities are concentrated in only around 30 (thirty) districts/cities. This has resulted in a widening gap in economic development between regions. One of the obstacles faced by investors in exploring investment is the lack of information on investment potential and infrastructure support in the regions [24]. It also becomes a challenge in the global context for investment management within investment promotion effectively [25]. This matter also can be viewed as the impact of the challenges, which showed in the criteria for "ease of doing business" [26], where Indonesia's position is at level 73 out of 190 countries [27].

Table 1 is presented as a normative idea in fulfilling the role of ISRIP. Normatively, we refer to integrated thinking that is in accordance with integrated reporting [11][12][19] within creating value over time. Furthermore, the organization's business model is used in the investment management cycle [8]. As explained by the OECD [1], there are 3 (three) perspectives in investment management. The development model also refers to a perspective [25] which emphasizes the importance of a strategic approach to SDGs. In line with the idea, regarding the role of information systems for investment, namely by aligning investment with SDGs and putting real data behind the word 'impact' [8]. Regional governments need to fulfill guarantees that investment management communications with the ISRIP design can be accounted for sustainable development [7]. For important reasons as stated, normative ideas are put forward in the 'integrated thinking component according to $<\mathrm{IR}>$ [11], [12], [19] for the development of ISRIP" [4][5].

Table 1 shows the idea of using the pillars of best practices of investment management adopted as the important cycle of investment management. The development of information system of regional investment potential (ISRIP) that is represented by the achievement of this performance of the information system. First, the application of complete information on the profile of regional investment units with a benchmark for 6 (six) capital of integrated reporting $<\mathrm{IR}>$ aspects. Second, by system strengthening with a communication strategically through by ISRIP of regional government.

In the context of regional investment unit information criteria, regional governments refer to [4] with information representation of regional investment units. As description (Table 1) is representation of information criteria. All information presented in ISRIP is related to information needs for investors, in analyzing and evaluating for the sustainability investment opportunities of the offered regional investment units. 
Table 1. The integrated thinking's components fit with $<\mathrm{IR}>$ for ISRIP development

\begin{tabular}{|c|c|c|c|}
\hline $\begin{array}{l}\text { Integrated thinking (IT) fit } \\
\text { with integrated reporting }\end{array}$ & \multicolumn{3}{|c|}{ ISRIP development } \\
\hline $\begin{array}{l}\text { What information is } \\
\text { connected and how } \\
\text { information is connected }\end{array}$ & \multicolumn{2}{|c|}{ Content of information within regional investment units into ISRIP } & $\begin{array}{l}\text { Strategic regional investment } \\
\text { management communication } \\
\text { within ISRIP }\end{array}$ \\
\hline Connecting strategy & Information for regional investment units & $\begin{array}{l}6(\text { six })<\mathrm{IR}> \\
\text { capital }\end{array}$ & \\
\hline Governance & $\begin{array}{l}\text { Description of investment opportunities, market } \\
\text { opportunities, estimated investment value, } \\
\text { feasibility to offer }\end{array}$ & $\begin{array}{l}\text { Financial } \\
\text { (economic } \\
\text { measures) }\end{array}$ & $\begin{array}{l}\text { Coordinating a cross level of } \\
\text { government and polices. }\end{array}$ \\
\hline Past performance & Human resources: feasibility to offer & Human & $\begin{array}{l}\text { Strengthen capacities at all levels } \\
\text { of government. }\end{array}$ \\
\hline Future prospect & $\begin{array}{l}\text { Facilities and infrastructure: production and } \\
\text { investment scale offered, available } \\
\text { infrastructure, supporting industries, feasibility } \\
\text { to offer }\end{array}$ & Manufacture & $\begin{array}{l}\text { Proper framework conditions for } \\
\text { public investment at all level of } \\
\text { government. }\end{array}$ \\
\hline \multirow[t]{3}{*}{$\begin{array}{l}\text { Connecting functional } \\
\text { department }\end{array}$} & $\begin{array}{l}\text { SME's stakeholders and large entrepreneurs, } \\
\text { feasibility to offer }\end{array}$ & Social & $\begin{array}{l}\text { Sourcing and due diligence of } \\
\text { screening investments to advance } \\
\text { an SDG }\end{array}$ \\
\hline & $\begin{array}{l}\text { Support of regional regulations, regulatory } \\
\text { aspects, land ownership status, feasibility to offer }\end{array}$ & $\begin{array}{l}\text { Intellectual } \\
\text { propert right }\end{array}$ & $\begin{array}{l}\text { Investment selection and } \\
\text { structuring (analysis and } \\
\text { verification) }\end{array}$ \\
\hline & $\begin{array}{c}\text { General condition of the area, availability of land } \\
\text { for development, environmental aspects, } \\
\text { feasibility to offer }\end{array}$ & $\begin{array}{c}\text { Natural } \\
\text { (environment) }\end{array}$ & $\begin{array}{l}\text { Measuring and reporting progress } \\
\text { made toward the SDGs }\end{array}$ \\
\hline
\end{tabular}

(Sources: [19], [1], [11], [12], [13], [14], [25], [8], [4],[5])

Table 2. Information criteria within a regional investment unit

\begin{tabular}{ccc}
\hline Information criteria for regional investment units & Information on analysis results & $\begin{array}{c}\text { Information on the results } \\
\text { of factual verification }\end{array}$ \\
\hline The object offered (name of the investment unit) & Name of regional investment unit & $\begin{array}{c}\text { Name of regional } \\
\text { investment unit }\end{array}$ \\
\hline Availability of raw materials & There is (name of place) & Support \\
\hline Availability of competent human resources & There are graduate educational institutions available & Support \\
\hline Availability of facilities and infrastructure & complete facilities and infrastructure available & Support \\
\hline Short term and long term market & The existence of a captive market for the products & Sroduced \\
\hline Domestic and foreign markets & There is a captive market for domestic and abroad & Support \\
\hline $\begin{array}{c}\text { The involvement of small and medium } \\
\text { stakeholders and large entrepreneurs }\end{array}$ & There are areas for SMEs and partnership facilities & Support \\
\hline Compliance with statutory regulations & $\begin{array}{c}\text { Already have principal permits and and other related } \\
\text { regulations }\end{array}$ & Support \\
\hline Environmental aspects & there has been an analysis of environmental impact \\
studies & Support \\
\hline Land availability and status and ownership & $\begin{array}{c}\text { already controlled by the area manager with an area (... } \\
\text { hectares), available land (...... hectares) } \\
\text { (money term) }\end{array}$ & Support \\
\hline Estimated investment (IDR) & --- & Support \\
\hline Eligibility to be offered to investors & & worth offering to investors \\
\hline
\end{tabular}

(Source: [4])

The management of ISRIP requires aligning both strategic and technical aspects. First is strategic, because ISRIP is part of investment promotion carried out through the function and role of the "Indonesia Investment Promotion Center (IIPC). In investment management, the functions and roles of ISRIP be integrated [25], [8], [4], [28], [5], to achieve the strategic objectives in line with SDGs [7]. Therefore, strategically, fulfilling the information criteria for communication of regional investment units is needed as a strategic way to fulfill objectives that are in line with the functions and roles of the IIPC. In accordance with the functions and roles of the IIPC, the function orientation and strategic role of ISRIP is directed at fulfilling several tasks and functions, namely: (i) 1. Increase investment from domicile countries and working areas to Indonesia; (ii) Facilitating investment from Indonesia to domicile countries and working areas. Second, from an information technology perspective, 
because ISRIP is an integrated part of the National Single Window for Investment (NSWI) [28]. Functionally, for operational capability, ISRIP is managed through its implementation at the Regional Government Investment Service. Become an integrated part of the joint sitemap in NSWI, namely with a homepage for the public (individuals/communities), and for investors (individuals or companies).

Based on the explanation regarding investment management to fulfill the role of ISRIP performance, then the approach described (Table 1 and Table 2) can be used. Therefore, in general, the approach to fulfilling the information criteria alignment for the regional investment profile represented in the fulfillment of 6 (six) integrated reporting capital $<\mathrm{IR}>$ [11], [12], [19], [13], [14] is relevant to be implemented in ISRIP. Then strategically by laying a foundation based on strategic communication investment management [25], [8], [4], [28], [5], to achieve the strategic objectives in line with SDGs [7]. Both of these perspectives are relevant approaches to be applied in the effort to achieve sustainable development from regional investment management through the role of ISRIP in regional governments.

Some previous studies [29], [30], [20], [31], [32], [33], [34] were put forward as contextual discussing for this research. The study previously showed using theory such as legitimacy and stakeholder theories in environmental control through an organizational reporting approach [9], [35]. Study for role of country -and firm-level determinants in environmental, social, and governance disclosure [9], [35], [36]. Other studies [21], [37] showed research themes for different study subjects. Then research related to best practice reporting $<\mathrm{IR}>$ on 164 company organizations around the globe [38]. As well as a study on disclosure of social investment through the role of $<\mathrm{IR}>$ [39].

Our research is carried out as an effort to answer questions related to aspects of regional investment management, to support sustainable development with the role of an integrated regional investment potential information system based on integrated thinking. The study is carried out based on the relevant legitimacy theory used to explain and control what will be planned and realized. The study is carried out based on the extensively used the legitimacy theory to explain and control for what to be planned and to be realized. With accountability for investment as social contracts point of view. Also, it relates to stakeholder theory within fulfillment the performance accountability [9]. Research uses aspects in the integrated thinking model with their alignment in the integrated reporting system [11], [12], [19], [13], [14] within the implementation of ISRIP [4], [5].

\section{Research Methods}

This section describes the approach used in the study, identified the sample unit and unit of analysis, data collection process approach, and data analysis process approach. This research is a quantitative research using non-parametric statistical analysis tool.

\subsection{Sample and Unit of Analysis}

The research sample is regional government in Indonesia that manages the information system of regional investment potential (ISRIP). The units of analysis are regional investment units as investment profiles offered to investors through ISRIP communications. Regional investment units are classified into 3 (three) regional investment classifications, namely: (i) potential investment (P), (ii) priority investment (Pr), and (iii) investment that has an opportunity (Opportunity (O)) ready to offer [4]. The selection for sample unit and for the unit of analysis are carried out with gradual judgment sampling on a cluster basis. With top down and bottom up investment management approaches [4]. This stage resulted into 3 (three) research sample clusters, namely: (i) selected sample for 4 (four) provinces with 8 (eight) regional government entities (district/cities) (top down approach) [4]. (ii) selected sample for East Kalimantan Province (contemporary issue of being the new capital city for Indonesia [40], bottom up approach [4]. (iii). Determination of samples at the government entities of South Kalimantan Province (related contemporary issues as the gateway to the new capital city of the State, bottom up approach [4]. The second stage is the selection within regional investment units within selected regional government, with investment criteria: (i) potential investment criteria to be carried out (in accordance with development plans, sectoral strategic plans, investment locations and spatial plans, linkages between sectors, can be cover costs, preliminary studies), (ii) priority investment criteria to be carried out (regional government proposals or investor requests, pre-feasibility studies, identified risk management, proposed priority public-private partnership programs, government support for identification of poverty alleviation investments), ( iii) investment criteria that are ready to be offered (complete investment supporting documents, government approval support, administrative readiness related to the realization of investment programs/activities/projects) [4]. Results of sample selection and unit analysis: (i) with 48 (forty eight) regional investment units in the top down cluster, (ii) with 24 (twenty four) regional investment units in the bottom up cluster and (iii) with selected sample for 28 (twenty eight) regional investment units in the bottom up cluster. This amount is considered sufficient [41] for the purposes of analysis and for conclusions.

\subsection{Variables and Measurement}

The operational definitions of variables, indicator items and their measurement are presented in Table 2. The 
operational definition of IR was for what information is connected, towards potential investment, priority investment, and leading investment opportunities, while for dependent variable of ISRIP is operationally related as Implementation of six $<\mathrm{IR}>$ capital for ISRIP. More specifically, It is defined as in central connectivity for completeness of information within regional investment units to be informed into six $<\mathrm{IR}>$ capital that can be reported within ISRIP. Meanwhile, Implementation for strategic communication of ISRIP was related to the functional connection between regional governmental work units internally, and with other level of government externally towards performance of ISRIP. The detail of items was explained in Table 3.

\begin{tabular}{|c|c|c|c|}
\hline Variable & Item & Reference & Scale \\
\hline \multirow[t]{5}{*}{$\begin{array}{l}\text { Integrated } \\
\text { Reporting } \\
\text { (X) }\end{array}$} & $\begin{array}{l}\text { Connecting strategy } \\
\text { (X1) }\end{array}$ & \multirow{5}{*}{$\begin{array}{c}{[11],[12],} \\
{[4],[21]}\end{array}$} & \multirow{5}{*}{ Nomina } \\
\hline & Governance (X2) & & \\
\hline & Past performance (X3) & & \\
\hline & Future prospect (X4) & & \\
\hline & $\begin{array}{l}\text { Connecting functional } \\
\text { departments (X5) }\end{array}$ & & \\
\hline \multirow[t]{2}{*}{ ISRIP (Y) } & $\begin{array}{l}\text { Implementation of } \\
\text { information system of } \\
\text { regional investment } \\
\text { potential (ISRIP) (Y1) }\end{array}$ & $\begin{array}{c}{[11],[12],} \\
{[19],[4]}\end{array}$ & \multirow[t]{2}{*}{ Nomina } \\
\hline & $\begin{array}{l}\text { Implementation for } \\
\text { strategic communication } \\
\text { of ISRIP (Y2) }\end{array}$ & $\begin{array}{l}\text { 11], [12], } \\
{[19],[4],} \\
{[25],[8]}\end{array}$ & \\
\hline
\end{tabular}

The independent variable and the dependent variable of this study with each indicator item be measured by a nominal scale. Measurement using items of indicator of each research variable towards the research analysis unit (regional investment unit) with the type of potential investment $(\mathrm{P})$, priority $(\mathrm{Pr})$ and investment ready to offer (O). In accordance with the nominal measurement scale, direct measurements are made with the relevant documentation source [4], [5]; general investment plan document (online data reference related to regional investment) related to the study subject). For measurements that indicate the indicator item is met in the investment profile of the regional investment unit, the value is given 1. Meanwhile, for the measurement that shows the characteristics of the indicator items that are not yet fulfilled in the information on the investment profile form each of the regional investment unit, it is given a value of 0 .

\subsection{Data Analysis}

The results of direct measurement of the indicator items of the alignment of the information criteria in the regional investment unit profile $(\mathrm{P} / \mathrm{Pr} / \mathrm{O})$ are then used in the analysis phase. In accordance with the research objectives, the results of the analysis are used to assess the propositions in the first statement, whether there is a difference, and for the second statement whether there is a relationship between the variables. For data analysis and testing of hypothesis statements (Ho1 and Ho2) used non-parametric statistical test tools, namely the chi-Square goodness of fit test or the chi-square test for independence [42]. With using the chi-square test tool and the use of the contingency within measure the frequency of observation (OF) and the expected frequency (EF), to value of test difference of hypotheses (Ho1). Then to test the level of relationship between variables (Ho2) is used the correlation test with referring to the $\mathrm{C}$-contingency value. For the analysis stage and fulfillment of the conclusions of this study, we also use a focus group discussion (FGD) approach as a semi-structured discussion forum. And by conducting field research for 1 (one) district that is currently developing to upload data to ISRIP as a role model for this research. Several key people were involved in making the statement. As part of thoughts and ideas related to efforts to develop investment management according to regional conditions in the context of investment promotion nationally and globally.

\section{Result and Discussion}

Hypothesis testing for the difference test (H01) and for the relationship test (H02) was carried out using the chi-square test for goodness of fit. First, testing for the Ho1 hypothesis is done by comparing the $\mathrm{X} 2$ table with the $\mathrm{X} 2$ observation as the basis for acceptance or rejection of the hypothesis research H01. Second, to assess the closeness of the relationship between variables $\mathrm{X}$ and $\mathrm{Y}$ within the hypothesis research $\mathrm{H} 02$, be valued, after obtaining the results of the chi square difference test, with a measure of the contingency coefficient (C Contingency). The data in Table 4 are the basis for testing the research hypothesis.

Hypothesis Testing $\left(\mathrm{HO}_{1}\right)$, is a test for different tests in the application of aspects from the dimensions of integrated thinking (IT) with the implementation of a regional investment potential information system (ISRIP). Testing by measuring the frequency of observation (OF) with the expected frequency (EF) whichever is the greater the frequency. The measurement results show that the observation frequency reaches a value of 137.97. Then for the expected frequency (EF) which is determined by referring to the degrees of freedom of rows and columns (6-1) (7-1) with a significance level of 0.05 , the frequency value in the chi squared table is 43.77 . Based on the comparison of X2 observation 137.97 which is greater than X2 table 43.77, this means that Ho1 can be rejected, at the chi-square significance value $<0.05$. The results of testing this hypothesis indicate that there are differences in the application of the Regional Investment Potential Information System (ISRIP) and the fulfillment of the integrated thinking aspect. These results also mean that fulfillment of (connecting strategy, governance, past 
performance, future prospects and connecting functional regional government's ISRIP role. departments) provides performance outcomes in the

Table 4. Observation frequency (OF) and expectation frequency (EF)

\begin{tabular}{|c|c|c|c|c|c|c|c|c|}
\hline Variables & Conn Str & Govern & Past Perf & $\begin{array}{l}\text { Future } \\
\text { Pros }\end{array}$ & $\begin{array}{l}\text { Conn } \\
\text { Dept }\end{array}$ & $\begin{array}{c}\text { Six }<\text { IR }> \\
\quad \mathrm{C}\end{array}$ & $\begin{array}{c}\text { Cont El } \\
<\mathrm{IR}>\end{array}$ & Amount \\
\hline \multicolumn{9}{|c|}{$\begin{array}{l}\text { The rhetorical components of } \\
\text { integrated thinking fit with } \\
\qquad<\mathrm{IR}>\end{array}$} \\
\hline \multicolumn{9}{|c|}{$\begin{array}{c}\text { Very Rhetorical Component } \\
\text { IT \& IR }\end{array}$} \\
\hline Score $6(\mathrm{OF})$ & 28 & 32 & 32 & 63 & 75 & 73 & 89 & 392 \\
\hline $\mathrm{Fe}$ & 56 & 56 & 56 & 56 & 56 & 56 & 56 & \\
\hline \multicolumn{9}{|c|}{$\begin{array}{l}\text { Rhetorical Component IT \& } \\
\text { IR }\end{array}$} \\
\hline Score $5(\mathrm{OF})$ & 42 & 25 & 43 & 24 & 8 & 15 & 1 & 158 \\
\hline $\mathrm{Fe}$ & 22.5714 & 22.5714 & 22.5714 & 22.5714 & 22.5714 & 22.5714 & 22.5714 & \\
\hline \multicolumn{9}{|c|}{ Rhetorical Enough } \\
\hline Score $4(\mathrm{OF})$ & 19 & 32 & 23 & 11 & 3 & 1 & 10 & 99 \\
\hline $\mathrm{Fe}$ & 14.1428 & 14.1428 & 14.1428 & 14.1428 & 14.1428 & 14.1428 & 14.1428 & \\
\hline \multicolumn{9}{|l|}{ Less Rhetorical } \\
\hline Score 3 (OF) & 11 & 9 & 2 & 1 & 8 & 11 & 0 & 42 \\
\hline $\mathrm{Fe}$ & 6 & 6 & 6 & 6 & 6 & 6 & 6 & \\
\hline \multicolumn{9}{|c|}{ Very Less Rhetorical } \\
\hline Score 2 (OF) & 0 & 2 & 0 & 1 & 4 & 0 & 0 & 7 \\
\hline $\mathrm{Fe}$ & 1 & 1 & 1 & 1 & 1 & 1 & 1 & \\
\hline \multicolumn{9}{|l|}{ Bad Rhetorical } \\
\hline Score $1(\mathrm{OF})$ & 0 & 0 & 0 & 0 & 2 & 2 & 0 & 4 \\
\hline $\mathrm{Fe}$ & 0.5714 & 0.5714 & 0.5714 & 0.5714 & 0.5714 & 0.5714 & 0.5714 & \\
\hline Amount & 100 & 100 & 100 & 100 & 100 & 100 & 100 & 700 \\
\hline
\end{tabular}

Table 5. Contingency \& chi square observation

\begin{tabular}{|c|c|c|c|c|c|c|c|c|}
\hline Variables & Conn Str & Govern & Past Perf & Future Pros & Conn Dept & $\begin{array}{c}\text { Six }<\mathrm{IR}> \\
\text { Cap }\end{array}$ & $\begin{array}{c}\text { Cont El } \\
<\mathrm{IR}>\end{array}$ & Amount \\
\hline & -28 & -24 & -24 & 7 & 19 & 17 & 33 & \\
\hline & 784 & 576 & 576 & 49 & 361 & 289 & 1089 & \\
\hline \multirow[t]{3}{*}{$\begin{array}{c}\text { Xo } \\
\text { Observation }\end{array}$} & 14 & 10.2857 & 10.2857 & 0.875 & 6.4464 & 5.1607 & 19.4464 & 35.4464 \\
\hline & 19.4285 & 2.42857 & 20.4285 & 1.42857 & -14.5714 & -7.5714 & -21.5714 & \\
\hline & 377.4693 & 5.8979 & 417.3265 & 2.0408 & 212.3265 & 57.3265 & 465.3265 & \\
\hline \multirow[t]{3}{*}{$\begin{array}{c}\text { Xo } \\
\text { Observation }\end{array}$} & 16.7233 & 0.2613 & 18.4891 & 0.0904 & 9.4068 & 2.5397 & 20.6157 & 35.5641 \\
\hline & 4.8571 & 17.8571 & 8.8571 & -3.1428 & -11.1428 & 2.8571 & -4.1428 & \\
\hline & 23.5918 & 318.8775 & 78.4489 & 9.8775 & 124.1632 & 8.1632 & 17.1632 & \\
\hline \multirow[t]{3}{*}{$\begin{array}{c}\text { Xo } \\
\text { Observation } \\
\end{array}$} & 1.6681 & 22.5468 & 5.5468 & 0.6984 & 8.7792 & 0.5772 & 1.2135 & 30.4603 \\
\hline & 5 & 3 & -4 & -5 & 2 & 5 & -6 & \\
\hline & 25 & 9 & 16 & 25 & 4 & 25 & 36 & \\
\hline \multirow[t]{3}{*}{$\begin{array}{c}\text { Xo } \\
\text { Observation } \\
\end{array}$} & 4.1666 & 1.5 & 2.6666 & 4.1666 & 0.6666 & 4.1666 & 6 & 12.5 \\
\hline & -1 & 1 & -1 & 0 & 3 & -1 & -1 & \\
\hline & 1 & 1 & 1 & 0 & 9 & 1 & 1 & \\
\hline \multirow[t]{3}{*}{$\begin{array}{c}\text { Xo } \\
\text { Observation }\end{array}$} & 1 & 1 & 1 & 0 & 9 & 1 & 1 & 14 \\
\hline & -0.5714 & -0.5714 & -0.5714 & -0.5714 & 1.4285 & 1.4285 & -0.5714 & \\
\hline & 0.3265 & 0.3265 & 0.3265 & 0.3265 & 2.0408 & 2.0408 & 0.3265 & \\
\hline $\begin{array}{c}\text { Xo } \\
\text { Observation }\end{array}$ & 0.5714 & 0.5714 & 0.5714 & 0.5714 & 3.5714 & 3.5714 & 0.5714 & 10 \\
\hline \multirow[t]{4}{*}{ Amount } & & & & $\begin{array}{c}\mathrm{X} 2 \\
\text { Observation }\end{array}$ & & & & 137.9709 \\
\hline & & & & $\mathrm{X} 2$ table & & & & 43.77 \\
\hline & & & & $\mathrm{N}$ & & & & 700 \\
\hline & & & & $\begin{array}{c}\mathrm{C} \\
\text { Contingency }\end{array}$ & & & & 0.4057 \\
\hline
\end{tabular}


Hypothesis testing is to assess the level of relationship between the variables from the different test results (H01). By calculating the value of the Pearson contingent

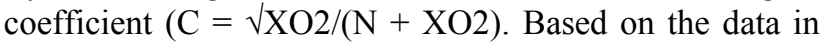
Table 5 (appendix- Contingency \& chi square observation), the value of $\mathrm{C}=\sqrt{ } 137.97 /(700+137.97)$ is obtained $=$ 0.4057 . Referring to Guilford's empirical rule, it shows that the $\mathrm{C}$-contingency value is a bounded association coefficient between $0<1$, where: $0=$ no association/relationship, and $1=$ perfect association/relationship. contingency $\mathrm{C}$ of 0.4057 can be expressed as "moderate correlation." These results indicate that there is a significant relationship with moderate correlation in the performance of the regional investment potential information system (ISRIP) through integrated thinking for completeness of information on six capital $<\mathrm{IR}>$, and with strategic communication in enhancing the role of ISRIP.

\section{Concluding Remarks}

The results of this study gave evidences form the basis for the coherence of an integrated thinking model that is in line with integrated thinking in the management of communication of regional investment units. The results of this study are empirical facts about the role clarity (future prospects, connected functional departments, implementation of six capital $<\mathrm{IR}>$ for ISRIP, and implementation for ISRIP strategic communication) in ISRIP implementation. These empirical facts are in line with a number of studies related to the integrated reporting aspect in creating value over time[30], [20], [31], [38], [32], [33], [34], [36]. The results of this study are also in line with Ratnatunga and Jones [29] in communicating the five bottom line theory of reporting with the reporting index criteria. Then with moderate results, where the empirical facts from aspects (connecting strategy, governance, and past performance) which have relatively low achievements in strengthening ISRIP performance, show alignment with the study perspective [37]. However, the results of the study provided moderate empirical facts that investment management has a relationship with a social contract perspective related to its decisions, with the theory of legitimacy and stakeholders in environmental control through an organizational reporting approach [9], [35].

In the context of managing Indonesia's regional investment for the ASEAN and global environment, it is necessary to implement the functions and roles of ISRIP [4][5]. This system is implemented formally by complying with national regulations (Law No. 25 of 2007). The functions and roles of ISRIP are fulfilled in relation to the suitability of the investment communication approach with the agreement in the AEC [43]. Because Indonesia is a member of the ASEAN Community and the integration of the AEC, investment management in the Indonesian region must be related to the ASEAN Comprehensive Investment Agreement (ACIA). This step is also in line with investment policies in the integration of development priorities and sectors for investment [43]. Furthermore, investment management within regional, however, should obey to enhance within compliance of the SDGs [7].

This study has limitations regarding the use of nominal scale measurement. Therefore, next research is needed with elevating the of the measurement scales, also with expanding the research sample. With the support of a more comprehensive study, a regional investment management policy should be able to receive input in a more substantive and massive manner.

\section{Acknowledgement}

We would like to extend our gratitude, and be thankful to Lambung Mangkurat University, and Faculty of Economic and Business with supporting for this research.

\section{REFERENCES}

[1] OECD. Effective Public Investment A Cross Levels of Government Principles for Action, 2014. Retrieved from http://www.oecd.org /effective-public-investment-toolkit/.

[2] Malmborg FB. Environmental Manaement Systems, Commuicative action and organizational learning, Business strategy and the environment, vol. 11, no. 5, pp. 312-321, 2002.

[3] International Organization for Standardization (ISO). ISO 14001: 2004, Environmental Management Systems, Geneva: International organization for Standardizations, 2004.

[4] CICB (BPKM), Laporan Akhir: Penyusunan Peta Potensi dan Peluang Investasi Daerah Tahun 2017 (Final Report on the Preparation of Regional Investment Potential and Opportunity Maps for 2017). Jakarta: Badan Koordinasi Penanaman Modal, 2017. Retrieved from http://info.trilogi.a c.id/repository/assets/uploads/AGB/e503d-laporan-kegiatan -potensi-investasi-daerah-bkpm-2017.pdf. (in bahasa)

[5] CICB (BKPM), Strategi Pengembangan Potensi Daerah dalam Peningkatan Iklim Investasi (Strategy for Developing Regional Potential in Increasing the Investment Climate), Jakarta: Badan Koordinasi Penanaman Modal, 2019. Retrieved from http://dpmptsp.riau.go.id/media/file/Strategi -Pengembangan-Potensi-Daerah-Dalam-Peningkatan-IklimInvestasi.pdf. (in bahasa)

[6] Kalev PS, Wallace D. Performance of Socially Responsible Investment Funds. In: Jones, S. \& Ratnatunga, J. eds. Contemporary issues in Sustainability accounting, assurance and reporting. pp. 43-70. Bingley: Emerald Publishing Limited, 2012.

[7] United Nation (UN). The Sustainable Development Agenda, 2017. Retrieved from https://www.un.org/sustainabledevelo pment/development-agenda-retired/. 
[8] Pineiro A, Dirheixh H, Dhar A. Financing The Sustainable Development Goals: Impact Investing in Action, Global Impact Investing Network (GIIN), 2018. Retrieved from https://thegiin.org/research/publication/financing-sdgs.

[9] Rankin M, Ferlauto K, McGowan SC, Stanton PA. Contemporary issues in accounting. Milton, Australia: Wiley; 2012.

[10] Reynolds G. Ethics in information technology. Cengage learning; 2014. Retrieved from www.cengage.com/highared.

[11] International Integrated Reporting Committee (IIRC). Towards Integrated Reporting: Communicating Value in the 21st Century, Discussion Paper, London: International Integrated Reporting Council, 2011.http://www.discussionp aper2011.theiirc. org.

[12] International Integrated Reporting Committee (IIRC). Consultation Draft of the International $<\mathrm{IR}>$ Framework, Discussion Paper, London: International Integrated Reporting Council, 2013. http://www.theiirc.org/consultatio ndraft2013.

[13] International Integrated Reporting Committee (IIRC). Breaking Through IIRC Integrated Report 2017, Discussion Paper, London: International Integrated Reporting Council, 2018. https://web: www.integratedreporting.org

[14] International Integrated Reporting Committee (IIRC). Integrated Thinking \& Strategy State of Play Report, Discussion Paper, London: International Integrated Reporting Council, 2019. https://www.integratedreporting.o rg.

[15] Jones H. Sustainability Reporting Matters: What Are National Governments Doing About It? pp. 1-40, London: Association of Chartered Certified Accountants, 2010 Retrieved form http://www.accaglobal.com/content/dam/acc a/global/PDF-technical/sustainability-reporting/tech-tp-srm. pdf.

[16] Slaper TF, Hall TJ. The triple bottom line: What is it and how does it work. Indiana business review, vol. 86, no. 1, pp. 4-8, 2011. Retrieved from https://www.ibrc.indiana.edu/ibr/2011 /spring/article2.html.

[17] Global Reporting Initiative (GRI). The sustainability content of integrated reports -a survey of pioneers, Research \& Development Series, Amsterdam: Global Reporting Initiative, 2013. Retrieved from https://www.slideshare.net/ APEXGlobal/the-sustainability-content-of-integrated-report s.

[18] Global Sustainability Standards Board (GSBB). GRI 203: Indirect Economic Impact. Amsterdam: Global Reporting Initiative, 2016. Retrieved from: https://www.globalreportin g.org/standards/media/1004/gri-203-indirect-economic-imp acts-2016.pdf.

[19] World Intellectual Capital Initiative (WICI). Connectivity: Background Paper for $<\mathrm{IR}>$. London: International Integrated

Reporting Council. Retrieved from https://integratedreportin g.org/wp-content/uploads/2013/07/IR-Background-Paper-C onnectivity.pdf.

[20] Adam CA. Six Capitals v The Triple Bottom Line. International Integrated Reporting Council. Posted April 8, 2015. Retrieved from https://integratedreporting.org/news/si $\mathrm{x}$-capitals-v-the-triple-bottom-line/
[21] Dumay J, Dai T. Integrated thinking as a cultural control? Meditari Accountancy Research, vol. 25, no. 4, pp. 574-604, 2017. https://doi.org/10.1108/ MEDAR-07-2016-0067.

[22] Özker AN. Tax Wedge Phenomenon and Its Possible Analytical Impacts on the Investments in OECD. Universal Journal of Accounting and Finance, vol. 8, no. 2, pp. 41 - 53, 2020. DOI: 10.13189/ujaf.2020.080202.

[23] Lleshaj L, Korbi A. Portfolio Selection and VaR Estimation: Evidence from Western Balkan Countries, Universal Journal of Accounting and Finance, vol. 8, no. 4, pp. 92 - 102, 2020 DOI: 10.13189/ujaf.2020.080402.

[24] Kristianus A. Lima Provinsi Masih Jadi Fokus: Investasi Bkpm Hadirkan Sistem PIR untuk Dorong Pemerataan. Investor Daily Indonesia (Oct 7, 2019), 2019. Retrieved from https://investor.id/business/bkpm-hadirkan-sistem-pir-untuk -dorong-pemerataan-investasi (in bahasa).

[25] United Nations Conference On Trade And Development (UNCTAD). Promoting Investment In The Sustainable Development Goals, Investment Advisory Series, Series A, Number 8. United Nations Publication, 2018a. Retrieved from

https://unctad.org/system/files/official-document/diaepcb20 $18 \mathrm{~d} 4$ en.pdf.

[26] World Bank. Doing Business 2019: Training for Reform. Washington D.C.: World Bank, 2018. https://doi.org/10.159 6/978-1-4648-1326-9.

[27] United Nations Conference On Trade And Development (UNCTAD), World Investment Report 2017: Investment and the Digital Economy. New York and Geneva: United Nations, 2018b. Retrieved from https://unctad.org/webflyer/world-in vestment-report-2017.

[28] CICB (BPKM). Nasional Single Window for Investment (NSWI), 2018, Organized by BKPM, https://nswi.bkpm.go.i $\mathrm{d} /$ sitemap.

[29] Ratnatunga J; Jones S. A Methodology to Rank the Quality and Comprehensiveness of Sustainability Information Provided in Publicly Listed Company Reports. In: Jones S; Ratnatunga J. eds. Contemporary issues in Sustainability accounting, assurance and reporting, pp. 227-266. Bingley: Emerald Publishing Limited, 2012.

[30] Adams CA. Resources for integrated report preparers and topics for researchers. Asian-Pacific Conference on International Accounting Issues. Posted November 11, 2013. Retrieved from https://drcaroladams.net/resources-for-integr ated-reporting-and-topics-for-researchers/.

[31] International Integrated Reporting Council (IIRC). Realizing the benefits: The impact of integrated reporting. London: International Integrated Reporting Council, 2014. Retrieved from

https://integratedreporting.org/wpcontent/uploads/2014/09/I IRC.Black_.Sun _Research.IR _.Impact.Single.pages.18.9.1 4.pdf.

[32] Bernardi C, Stark AW. Environmental, social and governance disclosure, integrated reporting, and the accuracy of analyst forecasts. The British accounting review. 2018 Jan 1;50(1):16-31. https://doi.org/10.1016/j.bar.2016.10.001

[33] Rivière-Giordano G, Giordano-Spring S, Cho C. Does the level of assurance statement on environmental disclosure 
affect investor assessment?. Sustainability Accounting, Management and Policy Journal. 2018 Jul 2;9(3):336-60. https://doi.org/10.1108/SAMPJ-03-2018-0054.

[34] Dragomir VD. How do we measure corporate environmental performance? A critical review. Journal of Cleaner Production, vol. 196, pp. 1124-57, 2018. https://doi.org/10.1 016/j.jclepro.2018.06.014.

[35] Mata C, Fialho A, Eugénio T. A decade of environmental accounting reporting: what we know?. Journal of Cleaner Production. 2018 Oct 10;198:1198-209. https://doi.org/10.1 016/j.jclepro.2018.07.087.

[36] Baldini M, Dal Maso L, Liberatore G, Mazzi F, Terzani S. Role of country-and firm-level determinants in environmental, social, and governance disclosure. Journal of Business Ethics. 2018 Jun;150(1):79-98. https://doi.org/10.1 007/s10551-016-3139-1

[37] Dumay J, Bernardi C, Guthrie J, La Torre M. Barriers to implementing the international integrated reporting framework: a contemporary academic perspective. Meditari Accountancy Research. vol. 25, no. 4, pp. 461-480, 2017. https://doi.org/10.1108/MEDAR-05-2017-0150.

[38] International Integrated Reporting Council (IIRC). What Better Reporting Looks Like. London: International
Integrated Reporting Council, 2017. Retrieved from https://integratedreporting.org/wp-content/uploads/2017/04/ What-Better-Reporting-Looks-Like1.pdf.

[39] Adams CA, Potter B, Singh PJ, York J. Exploring the implications of integrated reporting for social investment (disclosures). The British Accounting Review. 2016 Sep 1;48(3):283-96. https://doi.org/10.1016/j.bar.2016.05.002.

[40] JLL. Why Indonesia is attracting big investors for its new capital city, Article, 2020. Retrieved from https://www.jll.co.id/en/trends-and-insights/investor/why-in donesia-is-attracting-big-investors-for-its-new-capital-city.

[41] Wolf EJ, Harrington KM, Clark SL, Miller MW. Sample size requirements for structural equation models: An evaluation of power, bias, and solution propriety. Educational and psychological measurement. 2013 Dec;73(6):913-34. https://doi.org/10.1177\%2F0013164413495237.

[42] Conover WJ. Practical Nonparametric Statistics, 2nd Edition, New York: John Wiley \& Sons, 1980.

[43] AEC. ASEAN 2025: Forging Ahead Together. The ASEAN Community Vision 2025, the APSC Blueprint 2025 and the ASCC Blueprint 2025, 2015. Retrieved from https://www.asean.org/storage/2015/12/ASEAN-2025-Forgi ng-Ahead-Together-final.pdf. 